\title{
Targeting the TSH receptor in thyroid cancer
}

\author{
Christopher W Rowe1,2,3, Jonathan W Paul2,3, Craig Gedye3,4,5, Jorge M Tolosa ${ }^{2,3}$ \\ Cino Bendinelli2,6, Shaun McGrath ${ }^{1,2}$ and Roger Smith1,2,3
}

1Department of Endocrinology, John Hunter Hospital, Newcastle, Australia ${ }^{2} \mathrm{School}$ of Medicine and Public Health, University of Newcastle, Newcastle, Australia ${ }^{3}$ Hunter Medical Research Institute, Newcastle, New South Wales, Australia ${ }^{4}$ Department of Medical Oncology, Calvary Mater Newcastle, Waratah, Australia ${ }_{5}^{5}$ School of Biomedical Sciences and Pharmacy, University of Newcastle, Newcastle, Australia ${ }^{6}$ Department of Surgery, John Hunter Hospital, Newcastle, Australia
Correspondence should be addressed to $C$ Rowe Email

Christopher.Rowe@ hnehealth.nsw.gov.au

\begin{abstract}
Recent advances in the arena of theranostics have necessitated a re-examining of previously established fields. The existing paradigm of therapeutic thyroid-stimulating hormone receptor (TSHR) targeting in the post-surgical management of differentiated thyroid cancer using levothyroxine and recombinant human thyroid-stimulating hormone (TSH) is well understood. However, in an era of personalized medicine, and with an increasing awareness of the risk profile of longstanding pharmacological hyperthyroidism, it is imperative clinicians understand the molecular basis and magnitude of benefit for individual patients. Furthermore, TSHR has been recently re-conceived as a selective target for residual metastatic thyroid cancer, with pilot data demonstrating effective targeting of nanoparticles to thyroid cancers using this receptor as a target. This review examines the evidence for TSHR signaling as an oncogenic pathway and assesses the evidence for ongoing TSHR expression in thyroid cancer metastases. Priorities for further research are highlighted.
\end{abstract}

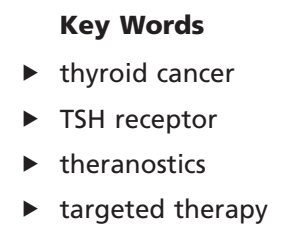

Endocrine-Related Cancer (2017) 24, R191-R202

\section{Introduction}

The thyroid-stimulating hormone (TSH) receptor (TSHR) is a surface glycoprotein receptor, part of the leucine-rich repeat subfamily of G-protein-coupled receptors (LGR). It has been described as the 'master switch' in regulating thyroid growth, differentiation and thyroid hormone secretion, and is the antigenic target in Graves' disease (Davies et al. 2005). TSHR is expressed on benign and malignant thyrocytes as the target receptor for TSH. In current clinical management of differentiated thyroid cancer (DTC), TSHR is therapeutically targeted to maximize radioiodine uptake into malignant thyrocytes by transiently upregulating the sodium-iodide symporter (NIS) through TSH stimulation, either endogenously through thyroid hormone withdrawal or exogenously with recombinant human TSH (rhTSH) (Haugen et al. 2016). Additionally, proliferative signals to malignant thyrocytes mediated through the TSHR are therapeutically minimized by inducing pharmacologic hyperthyroidism, resulting in endogenous TSH suppression. Recent scientific advances suggest new strategies to target TSHR in thyroid cancers, either using selective smallmolecule inhibitors of the TSHR to obviate the need for systemic hyperthyroidism or using the TSHR as a target to enhance the therapeutic index for drug delivery systems. This increased interest demands a critical appraisal of evidence for persistent TSHR expression in metastatic

Published by Bioscientifica Ltd 
Table 1 Data from studies of human extra-thyroidal tissue expression of TSHR.

\begin{tabular}{l} 
Tissue \\
\hline Adipose tissue \\
Adrenal \\
Endometrium \\
Erythrocytes \\
Extra-ocular muscle, adipocytes \\
Kidney \\
Liver \\
Lymphocytes \\
Pituitary \\
Hair follicles \\
Thymus \\
Vascular smooth muscle
\end{tabular}

\begin{tabular}{c} 
mRNA \\
\hline$Y$ \\
$Y$ \\
$Y$ \\
- \\
$Y$ \\
$Y$ \\
$Y$ \\
$Y$ \\
$Y$ \\
$Y$ \\
$Y$ \\
$Y$ \\
\hline
\end{tabular}

\begin{tabular}{ccc}
\hline Protein* & & Functionality* \\
\cline { 1 - 1 }$Y$ & & $Y$ \\
$Y$ & & - \\
$Y$ & & - \\
$Y$ & & $Y$ \\
$Y$ & $Y$ \\
$Y$ & & $Y$ \\
$Y$ & & $Y$ \\
$Y$ & & - \\
$Y$ & & - \\
- & & $Y$ \\
$Y$ & & - \\
$Y$ & $Y$ \\
\hline
\end{tabular}

References
Bell et al. (2000), Murakami et al. (2001), Gagnon et al. (2014)
Dutton et al. (1997)
Aghajanova et al. (2011)
Balzan et al. (2007)
Bahn et al. (1998), Valyasevi et al. (1999)
Dutton et al. (1997), Sellitti et al. (2000)
Zhang et al. (2009)
Chabaud and Lissitzky (1977), Coutelier et al. (1990)
Prummel et al. (2000), Theodoropoulou et al. (2000)
Bodo et al. (2009)
Murakami et al. (1996), Dutton et al. (1997)
Tian et al. (2014)

*Detected by immunohistochemistry, Western blot or ligand-binding assays. \#Assessed by increased cyclic AMP production/p70 S6 kinase or Na/K ATPase in response to TSH stimulation in vitro. -, not reported.

thyroid cancer. Herein, we review the evidence for TSHR signaling as a mitogenic pathway in thyroid cancers, assess the evidence for persistence of TSHR in advanced thyroid cancer and discuss new therapeutic strategies on the horizon.

\section{Structure and distribution of TSHR}

TSHR is a 764 amino acid 7-transmembrane domain receptor in the G-protein-coupled receptor superfamily. TSHR is encoded by the gene, thyroid-stimulating hormone receptor (TSHR), located on chromosome 14q31 and first cloned in 1989 (Parmentier et al. 1989). Although encoded by a single gene, the gene product undergoes post-translational cleavage into an extracellular A-subunit and a largely intracellular B-subunit linked by disulfide bonds, with the exclusion of a 50 amino acid C-peptide region (Rapoport \& McLachlan 2016). The A-subunit contains multiple binding sites for TSH within a leucinerich 'binding pocket', which undergoes conformational change after binding of TSH or stimulatory autoantibodies, resulting in receptor activation (Davies \& Latif 2015).

TSHR is predominantly expressed on the basolateral membrane of thyroid follicular cells. Surface expression of TSHR is estimated at 5000 receptors per cell (Rees Smith et al. 1988). TSHR mRNA and protein have been detected in a variety of other human and animal tissues, including neural and immune tissues, ocular muscles and bone (Davies et al. 2002, Williams 2011, Bassett \& Williams 2016). In particular, the role of TSHR expression in orbital preadipocytes and fibroblasts in the pathogenesis of Graves' ophthalmopathy has been extensively studied (Smith 2015), and there are animal data to support TSHR-mediated bone remodeling
(Abe et al. 2003, Ma et al. 2011). Human data regarding TSHR mRNA expression and protein production in extrathyroidal tissue are presented in Table 1 . We are not aware of studies that quantify TSHR receptor density in extrathyroidal tissue. In most extrathyroidal tissues the physiologic role of the TSHR remains unclear (Williams 2011).

\section{TSH as a growth factor for benign and malignant thyrocytes}

\section{TSH and intracellular growth signaling}

As a glycoprotein receptor in the rhodopsin family, TSHR responds to ligand binding with activation of its coupled $\mathrm{G}$ protein. Activation of $\mathrm{G} \alpha_{s}$ stimulates adenylate cyclase and activates the cyclic adenosine monophosphate (cAMP)/protein kinase A (PKA) pathway with wellestablished mitogenic effects, whereas $G \alpha_{q}$ stimulation results in the activation of protein kinase $\mathrm{B}$ and mitogenactivated protein kinase (MAPK) pathways (Morshed et al. 2009). The downstream effects are to increase the transcription of thyroid-specific genes, particularly controlling iodine uptake, synthesis of thyroglobulin and thyroperoxidase, with the end result of thyroid hormone production (Roger et al. 1988, Vassart \& Dumont 1992, Bruno et al. 2005). The regulation of thyrocyte growth has been extensively studied using in vitro models; however, it is well recognized that human in vivo confirmation of any such model is paramount (Kimura et al. 2001).

Bruno and coworkers (Bruno et al. 2005) demonstrated in vivo in humans that TSH regulates the transcription of NIS (SLC5A5), thyroglobulin (TG), thyroperoxidase (TPO) and paired box 8 (PAX8) mRNA, but not TSHR, pendrin

Published by Bioscientifica Ltd 
(SLC26A4) or thyroid transcription factor 1 (NKX2-1). Importantly, they showed that absence of TSH due to suppression from exogenous hyperthyroidism does not reduce TSHR mRNA. These data support the observations by Shuppert and coworkers (Shuppert et al. 1996) from human tissues that TSHR mRNA is not reduced in the presence of chronic stimulation by thyroid-stimulating autoantibodies and from Maenhaut and coworkers (Maenhaut et al. 1992) in dogs, confirming not only that TSHR is important in thyrocyte growth but also that TSHR gene transcription stably continues both in the presence and absence of its ligand. This contrasts with NIS gene and protein expression, which are affected by cellular signaling from iodine and TSH (Dohán et al. 2003).

\section{TSHR stimulation and thyroid growth}

Human disease states of chronic TSH stimulation provide in vivo models of TSHR-mediated thyroid growth, as seen in TSH-secreting pituitary adenomas, and Graves' disease (where TSHR stimulation occurs by thyroid stimulatory immunoglobulins (TSI) binding to TSHR). Both conditions are characterized by pathological thyroid enlargement, seen in $77 \%$ and 93\%, respectively (Hegedus et al. 1983, Beck-Peccoz et al. 2009). Additionally, chronic exposure to TSI has been associated with increased disease-specific mortality in thyroid cancer in some, but not all, studies (Belfiore et al. 1990, Pellegriti et al. 2013).

Recently, multiple large cohort studies have found that increased levels of serum TSH are associated with increased subsequent risk of thyroid cancer (Nieto \& Boelaert 2016). The largest study, recruiting 10,178 patients presenting with nodular thyroid disease for fine needle aspiration (FNA) biopsy, found an increasing odds ratio for papillary thyroid cancer (PTC) with incremental increases of TSH within the reference range of 0.43.4 IU/L (Fiore et al. 2009). Both higher pathological stage of the primary tumor and the increased incidence of nodal metastases were significantly associated with higher baseline TSH levels. In this study, level of TSH, not autoantibody status, was shown to be an independent variable in predicting malignancy.

Further, several studies have now shown the importance of TSHR signaling as part of the oncogenic pathway, particularly in tumors containing mutations in B-Raf proto-oncogene (BRAF). Franco and coworkers (Franco et al. 2011) showed in mice that $B R A F^{v 600 E}$ mutations were only oncogenic in the presence of a TSHR stimulatory pathway. This finding was confirmed by
Kim and coworkers (Kim et al. 2014) showing that TSH signaling overcomes senescence induced by BRAFV600E mutations in cell culture. Similarly, Lu and coworkers (Lu et al. 2010) used a TSHR-knockout mouse model of follicular thyroid cancer (FTC) to show that TSHRmediated growth signaling is required for thyroid cancer to metastasize, but only in the presence of additional oncogenic mutations.

\section{Suppressed TSH and reduced progression of thyroid cancer}

A correlation between a hyperthyroid state and reduced thyroid cancer growth was noted in the 1930s by the Australian surgeon Dunhill (1937). However, it was not until the 1950s that other surgeons, notably George Crile $\mathrm{Jr}$, began to widely advocate the practice of levothyroxine therapy to reduce the size of thyroid cancer metastases (Hurley 2011). Subsequently, multiple large studies, including a meta-analysis (McGriff et al. 2002), have confirmed that levothyroxine-induced suppression of TSH is associated with reduced growth of thyroid cancers. Key studies are reviewed below.

Mazzaferri and Jhiang (1994) prospectively followed 1355 patients with treated DTC. After 30 years, the rate of recurrence for patients treated with levothyroxine was $30 \%$, compared to $40 \%$ in untreated patients. Baseline characteristics of these subgroups, reasons for treatment and degree of suppression of TSH were not reported. Pujol and coworkers (Pujol et al. 1996) retrospectively compared a group of 18 patients with stable TSH $<0.05 \mathrm{IU} / \mathrm{L}$ with a group of 15 patients with stable TSH $>1 \mathrm{IU} / \mathrm{L}$ after thyroidectomy for DTC. Baseline characteristics were similar. Median relapse-free survival was twice as long in the suppressed TSH group (21.6 vs 9.3 years), with significantly fewer relapses over this period (1 vs 6 relapses). Cooper and coworkers (Cooper et al. 1998) followed 617 DTC patients from a thyroid cancer registry for median of 4.5 years, with patients grouped according to mean of measured TSH levels. In patients with advanced stage disease at diagnosis, greater TSH suppression was associated with higher rates of progression-free survival. Finally, Jonklaas and coworkers (Jonklaas et al. 2006) followed 2936 DTC patients from a multi-institutional registry. Patients with AJCC-TNM5 Stage 2 or higher disease had higher rates of overall survival with TSH levels below the reference range, with increased degrees of TSH suppression correlating with higher overall survival in Stages III and IV disease. 


\section{TSHR expression in in vitro models of thyroid cancer}

Although cell lines have represented an attractive model for cancer research for decades, it is increasingly understood that due to mutation and selection pressures within culture media, these cells commonly dedifferentiate. Several independent analyses of commonly studied thyroid cancer cell lines confirm that these cell lines have largely ceased to express markers of thyrocyte differentiation, and more closely represent anaplastic thyroid cancers than DTC (Meireles et al. 2007, van Staveren et al. 2007, Pilli et al. 2009). This is particularly true of TSHR expression, which is downregulated early in monolayer culture due to disruption of follicular architecture and loss of apical-basal polarity (Williams \& Wynford-Thomas 1997). In a recent review, Pilli and coworkers (Pilli et al. 2009) note that TSHR expression was not detected in any of a number of commonly studied cell lines. There are conflicting data regarding TSHR expression in the FTC-133 cell line (originating from a lymph node metastases of a differentiated human follicular thyroid cancer), with some authors demonstrating mRNA expression (D'Agostino et al. 2014) and TSH ligand binding (Paolino et al. 2014), which may represent heterogeneity within this cell line between laboratories. Additionally, there is conflicting evidence for TSHR expression in the BCPAP cell line (derived from a poorly differentiated PTC) (Pilli et al. 2009, D'Agostino et al. 2014, Dotan et al. 2016). Similarly, PTC cells grown in thyrosphere culture lack expression of thyroid-specific proteins, and cells fail to produce cAMP in response to TSH stimulation (Malaguarnera et al. 2011, Giani et al. 2015). The cell line XTC-UC1, derived from a metastatic Hurthle cell carcinoma, appeared to retain TSHR expression as well as other markers of differentiation (Zielke et al. 1998, Meireles et al. 2007), however, is no longer widely available. Consequently, cells stably transfected with TSHR are commonly used for in vitro targeting studies where reliable TSHR expression is desired.

\section{TSHR expression in primary thyroid tumors}

After seminal work by Ichikawa and coworkers (Ichikawa et al. 1976), robust evidence obtained over four decades supports the continued expression of TSHR in the majority of DTC, based on studies using ligand binding, mRNA detection using Western blotting or PCR and protein immunohistochemistry (IHC) (Table 2). Although TSHR mRNA and/or protein can be detected in over $90 \%$ of PTC and FTC, the relative expression of TSHR in different tumors is highly variable, both in terms of pattern and intensity of staining by IHC, and in the semi-quantitative analysis of mRNA recovery (Table 3 ).

Table 2 Evidence for TSHR expression in primary thyroid tumors and metastases.

\begin{tabular}{|c|c|c|c|c|c|c|c|c|c|c|c|c|c|c|c|c|c|}
\hline \multirow[b]{3}{*}{ Study } & \multirow[b]{3}{*}{ Method } & \multicolumn{8}{|c|}{ TSHR expression in primary tumors } & \multicolumn{8}{|c|}{ TSHR expression in lymph node metastases* } \\
\hline & & \multicolumn{2}{|c|}{ PTC } & \multicolumn{2}{|c|}{ FTC } & \multicolumn{2}{|c|}{ ATC } & \multicolumn{2}{|c|}{ MTC } & \multicolumn{2}{|c|}{ PTC } & \multicolumn{2}{|c|}{ FTC } & \multicolumn{2}{|c|}{ ATC } & \multicolumn{2}{|c|}{ MTC } \\
\hline & & $n$ & $\%$ & $n$ & $\%$ & $n$ & $\%$ & $n$ & $\%$ & $n$ & $\%$ & $n$ & $\%$ & $n$ & $\%$ & $n$ & $\%$ \\
\hline Carayon et al. 1980 & Ligand binding & $6 / 6$ & 100 & $2 / 4$ & 50 & $0 / 4$ & 0 & $0 / 4$ & 0 & $5 / 5$ & 100 & $6 / 7$ & 86 & $0 / 1$ & 0 & $0 / 1$ & 0 \\
\hline Clark et al. 1983 & Ligand binding & $10 / 10$ & 100 & $\leftarrow$ & $\leftarrow$ & - & - & - & - & - & - & - & - & - & - & - & - \\
\hline Brabant et al. 1991 & mRNA & $8 / 8$ & 100 & $1 / 1$ & 100 & $1 / 3$ & 33 & - & - & $6 / 6$ & 100 & - & - & $0 / 1$ & 0 & - & - \\
\hline Ohta et al. 1991 & mRNA & $3 / 3$ & 100 & $4 / 4$ & 100 & - & - & - & - & - & - & - & - & - & - & - & - \\
\hline Hoang-Vu et al.1992 & mRNA & $19 / 20$ & 95 & $6 / 8$ & 75 & $0 / 5$ & 0 & - & - & - & - & - & - & - & - & - & - \\
\hline Shi et al. 1993 & mRNA & $13 / 20$ & 65 & $2 / 2$ & 100 & $1 / 3$ & 33 & - & - & - & - & - & - & - & - & - & - \\
\hline Elisei et al. 1994 & mRNA & $16 / 16$ & 100 & $2 / 2$ & 100 & $0 / 2$ & 0 & $3 / 6$ & 50 & $4 / 4$ & 100 & - & - & - & - & $0 / 1$ & 0 \\
\hline Arturi et al. 1997 & mRNA & - & - & - & - & - & - & - & - & $23 / 23$ & 100 & $3 / 3$ & 100 & - & - & - & - \\
\hline Lazar et al. 1999 & mRNA & $38 / 38$ & 100 & $5 / 5$ & 100 & - & - & - & - & - & - & - & - & - & - & - & - \\
\hline Tanaka et al. 2000 & mRNA & $31 / 31$ & 100 & - & - & - & - & - & - & $4 / 4$ & 100 & - & - & - & - & - & - \\
\hline Park et al. 2000 & mRNA & $23 / 23$ & 100 & - & - & - & - & - & - & - & - & - & - & - & - & - & - \\
\hline Wang et al. 2011 & mRNA & $31 / 32$ & 97 & $\leftarrow$ & $\leftarrow$ & - & - & - & - & - & - & - & - & - & - & - & - \\
\hline Wang et al. 2011 & IHC, frozen & $32 / 32$ & 100 & $\leftarrow$ & $\leftarrow$ & - & - & - & - & - & - & - & - & - & - & - & - \\
\hline Tanaka et al. 1997 & IHC, frozen & $21 / 21$ & 100 & $2 / 2$ & 100 & - & - & - & - & - & - & - & - & - & - & - & - \\
\hline Gerard et al. 2003 & IHC, FFPE & $16 / 16$ & 100 & $14 / 14$ & 100 & - & - & - & - & $1 / 1$ & 100 & $2 / 2$ & 100 & - & - & - & - \\
\hline Matsumoto et al. 2008 & IHC, FFPE & $23 / 23$ & 100 & $\leftarrow$ & $\leftarrow$ & $0 / 8$ & 0 & - & - & - & - & - & - & - & - & - & - \\
\hline So et al. 2012 & IHC, FFPE & $18 / 20$ & 90 & - & - & - & - & - & - & $39 / 52$ & 75 & - & - & - & - & - & - \\
\hline Lin et al. 2016 & $\mathrm{IHC}$ & $37 / 46$ & 80 & - & - & - & - & - & - & - & - & - & - & - & - & - & - \\
\hline Liu et al. 2016 & $\mathrm{IHC}$ & $102 / 150$ & 68 & - & - & - & - & - & - & - & - & - & - & - & - & - & - \\
\hline
\end{tabular}

*Data from Elisei et al. included 2 local (non-lymph node) recurrences. Location of metastases was not reported by Tanaka et al. or Gerard et al. $\leftarrow$, data for PTC and FTC grouped together; dash, no data; FFPE, formalin fixed paraffin embedded; frozen: frozen tissue; IHC, immunohistochemistry. 
Table 3 Relative expression of TSHR in primary and metastatic DTC.

\begin{tabular}{|c|c|c|c|c|c|c|c|c|c|c|}
\hline \multirow[b]{2}{*}{ Author } & \multirow[b]{2}{*}{ Method } & \multirow{2}{*}{$\begin{array}{l}\text { Comparison } \\
\text { tissue }\end{array}$} & \multicolumn{8}{|c|}{ Tumoral TSHR expression relative to comparison tissue } \\
\hline & & & Increased & $\%$ & Similar & $\%$ & Reduced & $\%$ & Absent & $\%$ \\
\hline \multicolumn{11}{|l|}{ Primary DTC } \\
\hline Carayon et al. 1980 & Ligand binding & Normal & $1 / 10$ & 10 & $2 / 10$ & 20 & $5 / 10$ & 50 & $2 / 10$ & 20 \\
\hline Clark et al. 1983 & Ligand binding & Normal & $6 / 10$ & 60 & $2 / 10$ & 20 & $2 / 10$ & 20 & $0 / 10$ & 0 \\
\hline Brabant et al. 1991 & mRNA, frozen & Normal & - & - & - & - & $5 / 5$ & 100 & - & - \\
\hline Shi et al. 1993 & mRNA, frozen & MNG & $0 / 22$ & 0 & $4 / 22$ & 18 & $9 / 22$ & 41 & $9 / 22$ & 41 \\
\hline Tanaka et al. 1997 & IHC, frozen & Normal & $4 / 21$ & 19 & $7 / 21$ & 33 & $10 / 21$ & 48 & $0 / 21$ & 0 \\
\hline Sheils et al. 1999 & mRNA, FFPE & Normal & $2 / 76$ & 3 & $34 / 76$ & 45 & $40 / 76$ & 53 & $0 / 76$ & 0 \\
\hline Matsumoto et al. 2008 & IHC, FFPE & Normal & $16 / 23$ & 70 & - & - & $7 / 23$ & 30 & $0 / 23$ & 0 \\
\hline Wang et al. 2011 & mRNA/IHC, FFPE & Relative & $20 / 32$ & 63 & $7 / 32$ & 22 & - & - & $5 / 32$ & 16 \\
\hline So et al. 2012 & IHC, FFPE & Relative & $7 / 20$ & 35 & $9 / 20$ & 45 & $1 / 20$ & 5 & $2 / 20$ & 20 \\
\hline \multicolumn{11}{|l|}{ Metastases of DTC } \\
\hline Carayon et al. 1980 & Ligand binding & Normal & $0 / 14$ & 0 & $2 / 14$ & 14 & 9/14 & 64 & $3 / 14$ & 21 \\
\hline So et al. 2012 & IHC, FFPE & Primary tumour & $23 / 52$ & 44 & $24 / 52$ & 46 & $5 / 52$ & 10 & $0 / 52$ & 0 \\
\hline
\end{tabular}

-, no data reported; DTC, differentiated thyroid cancer; FFPE, formalin fixed, paraffin embedded; frozen, frozen tissue; IHC, immunohistochemistry; MNG, multinodular goiter; normal, normal thyroid tissue.

Sheils and Sweeny (1999) used PCR to semiquantitatively study mRNA extracted from 90 formalinfixed paraffin-embedded (FFPE) thyroid tumors, expressed as a ratio of TSHR mRNA to the housekeeping enzyme glyceraldehyde-3-phosphate dehydrogenase (GAPDH), and stratified by tumor type and degree of differentiation. Although TSHR mRNA was detected in all tumors, they found a significant positive correlation between degree of differentiation and TSHR expression (Fig. 1). Recovery of TSHR mRNA from medullary thyroid cancer (MTC) would not usually be expected given the neuroendocrine origin of these cells and could suggest contamination of samples from surrounding normal thyroid tissue; however, the finding is consistent with other studies suggesting MTC may in fact express the TSHR (Elisei et al. 1994).

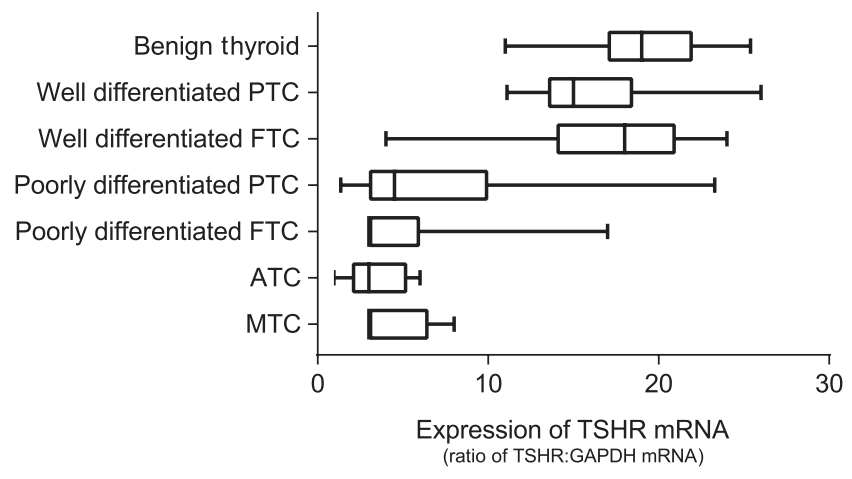

Figure 1

Box (25-75\%) and whisker (5-95\%) plot of TSHR mRNA expression by tumor type and differentiation. Redrawn with permission from data in Sheils and coworkers (Sheils et al. 1999). TSHR mRNA expressed as a ratio of the housekeeping gene GAPDH.
Tanaka and coworkers (Tanaka et al. 1997) studied TSHR protein expression in 21 PTCs (18 well differentiated) and 2 FTCs (both well differentiated) using IHC. They compared receptor immunostaining intensity and distribution to surrounding thyroid tissue. They found that intensity of staining for TSHR was weaker in $43 \%$, similar in $30 \%$ and increased in $17 \%$ of tumors, with TSHR intensity reported as homogenous in $57 \%$ and heterogenous in $43 \%$. Tumors with weaker TSHR staining were more likely to have an aggressive clinical phenotype.

In most studies, no TSHR expression was detected in anaplastic thyroid cancer (ATC), which is consistent with the expected loss of differentiation in this phenotype (Table 2).

\section{TSHR expression in thyroid cancer metastases}

There is a paucity of data regarding TSHR expression in thyroid cancer metastases. As is evident from Tables 2 and 3, the majority of studies of TSHR mRNA expression or TSHR protein levels have focused on primary thyroid tumors, with several studies including occasional metastases in their cohort, almost exclusively from neck lymph nodes. The largest and only systematic study of TSHR expression in DTC metastases is from So and coworkers (So et al. 2012), who examined using immunohistochemistry, the specific instance of subclinical lymph node metastases from papillary microcarcinoma, using 20 primary tumors and 52 associated subclinical central compartment metastases. They demonstrated that in their cohort, 90\% of primary tumors and $75 \%$ of metastatic nodes stained positive for TSHR, with concordance between primary

Published by Bioscientifica Ltd 
tumor and metastases demonstrated in $85 \%$ of cases. Intensity of staining was weaker in metastases than that in primary tumor in $44 \%$ of cases and similar or stronger in $56 \%$.

Arturi and coworkers (Arturi et al. 1997) used RT-PCR to study FNAs of enlarged neck lymph nodes from 27 patients with predominant PTC. In the 26 aspirates with adequate samples, TSHR mRNA was detected in all specimens. No details of patient or tumor characteristics were provided.

Evidence for persistent functional TSHR expression in thyroid cancer metastases can be inferred from detecting increased thyroglobulin production in response to TSH stimulation, as it occurs in preparation for radioiodine ablation in the context of known residual disease after thyroidectomy. Lippi and coworkers (Lippi et al. 2001) studied 12 patients with metastatic or locally invasive FTC $(n=10)$ or PTC $(n=2)$. In the 9 patients for whom data are available, thyroglobulin rose by a median of 8.4-fold (range 1.3-29×) after TSH stimulation. Luster and coworkers (Luster et al. 2000) report radioiodine treatment in 11 patients with advanced recurrent or residual DTC. Nine of 11 patients had previous radioiodine therapy (median 5 treatments). Ten of 11 patients had a rise in thyroglobulin after treatment with rhTSH (median $2.4 \times$ baseline, range 1.2-59.1). Jarzab and coworkers (Jarzab et al. 2003) studied administration of rhTSH in 54 patients with either locoregional or distant metastatic DTC. Fifty patients had received prior radioiodine ablation. Median serum thyroglobulin concentration increased 3.8-fold from baseline to day 6 after rhTSH. Individual patient data were not reported.

In a review of the 11 largest studies of rhTSH-assisted treatment of residual or recurrent DTC (124 patients), Luster and coworkers (Luster et al. 2005) found that serum thyroglobulin increased in response to rhTSH in at least $67 \%$ of patients for whom data were recorded. This figure is similar to the $75 \%$ prevalence of TSHR expression reported by So and coworkers (So et al. 2012) in papillary microcarcinoma and strongly suggests that TSHR expression is preserved in the majority of clinically significant DTC metastases and persists despite previous radioiodine exposure in the majority of cases. Importantly, this $67 \%$ is likely to underestimate actual TSHR expression in clinically significant metastases, both because these case series predominantly included patients with longstanding and advanced metastastic disease and because the surrogate outcome measure (thyroglobulin rise) relies on an intact multistep signaling cascade from TSHR to thyroglobulin production for a positive result.

\section{Persistence of TSHR expression in the setting of loss of other differentiation markers}

TSHR expression in DTC has been compared to the expression of other thyroidal markers of differentiation. Several studies have found that TSHR expression closely parallels other markers of differentiation, such as thyroglobulin and thyroperoxidase (Hoang-Vu et al. 1992, Elisei et al. 1994, Park et al. 2000). However, evidence from a number of studies of resected thyroid tissue suggests that TSHR is more persistently expressed than other differentiation markers, including NIS and thyroglobulin proteins (Filetti et al. 1999, Lazar et al. 1999, Gerard et al. 2003), indicating not only that TSHR may remain an important signaling pathway for cellular growth but also its utility as a conserved therapeutic target. Further in vivo evidence of continued TSHR expression in the absence of NIS is provided by a study of 63 patients with metastatic DTC, and no radioactive iodine uptake on whole body scan, who underwent ${ }^{18} \mathrm{~F}$-fludeoxyglucose positron emission tomography (18F-FDG-PET) both under basal conditions and after rhTSH stimulation (Leboulleux et al. 2009). This study found that the sensitivity of FDG-PET was significantly increased after rhTSH stimulation on a per lesion basis (95\% vs $81 \%$ ), suggesting that these lesions continued to express TSHR in the absence of the ability to concentrate radioiodine.

\section{Current therapeutic targeting of TSHR in DTC}

Firstly, as discussed previously, pharmacological TSH suppression with exogenous levothyroxine has been a mainstay of clinical DTC management for decades. However, the most recent guidelines of the American Thyroid Association now support a more individualized approach to TSH suppression, based on the likelihood of progressive residual disease and the risks associated with systemic hyperthyroidism (Haugen et al. 2016), better reflecting the paucity of evidence for benefit in low-risk patients. The long-term utility of TSH-suppressive therapy is limited in part by its tumoristatic, not tumoricidal, efficacy, although a survival benefit has been shown in high-risk patients (Jonklaas et al. 2006). However, in patients at lower risk of recurrence, the adverse effects of hyperthyroidism, including accelerated bone loss resulting in osteoporosis, and cardiac side effects, including atrial fibrillation, remain important caveats to universal therapy.

Published by Bioscientifica Ltc 
CURRENT TSHR TARGETING



FUTURE TSHR TARGETING

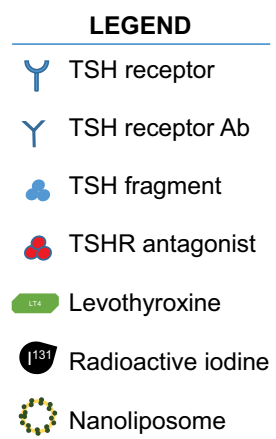

Figure 2

Schematic diagram outlining current and future theranostic targeting of TSHR in DTC. A full colour version of this figure is available at http://dx.doi. org/10.1530/ERC-17-0010.

Secondly, TSHR-mediated upregulation of NIS expression is routinely exploited in preparation for ablative radioiodine therapy, either with endogenous TSH stimulation by thyroxine withdrawal or pharmacologically with rhTSH. In clinical studies, expression of TSHR has been shown to correlate with the degree of iodine trapping (Edmonds et al. 1977), and with efficacy of ablation (Fallahi et al. et al. 2012). Further, both positive and negative regulation of NIS mRNA in response to TSHR stimulation has been demonstrated in human thyroid cells (Saito et al. 1997, Bruno et al. 2005). Interestingly, TSHR stimulation also increases the sensitivity of ${ }^{18} \mathrm{~F}-\mathrm{FDG}-$ PET imaging in the detection of residual metastatic disease, again suggesting that TSHR stimulation increases mitotic activity and glucose utilization within malignant thyrocytes (Leboulleux et al. 2009).

\section{Novel theranostic exploitation of TSHR}

Thus far, key characteristics have been identified that establish the TSHR as an attractive therapeutic target in DTC, namely its pivotal role in growth signaling, and its persistence as an expressed surface protein until late stages of de-differentiation. Additionally, the relative specificity of TSHR as a marker on thyroid tissue makes it an attractive potential target for novel theranostic and therapeutic agents. Over the last decade, there have been several exciting developments targeting TSHR in diagnosis or treatment of thyroid malignancies (Fig. 2).

\section{TSHR as a theranostic target for drug delivery}

New modalities for the localization and treatment of metastatic DTC are required, especially for tumors that are not cured by radioiodine. Although the majority of DTC has a favorable prognosis, up to $15 \%$ of cases do not respond completely to radioiodine ablation, including $4 \%$ that exhibit no tumor reduction or progressive disease (Sciuto et al. 2009). In cases that no longer concentrate radioiodine, the twin utility of radioiodine as a true theranostic agent (a modality with both diagnostic and therapeutic utility) is absent. Localization of recurrent disease is then reliant on structural imaging with ultrasound, computed tomography (CT) scan or ${ }^{18} \mathrm{~F}-\mathrm{FDG}-$ PET, which although sensitive, lacks the specificity of radioiodine avidity to confirm metastatic disease. Additionally, small molecule kinase inhibitors, which have surpassed traditional cytotoxics as first-line treatment for progressive radioiodine-resistant DTC, are cytostatic rather than tumoricidal, and thus, at best can prolong

Published by Bioscientifica Ltd 
progression-free survival rather than offer a chance of cure (Haugen et al. 2016). In addition, the toxicities of such agents preclude widespread use.

Late last century, Mayo Clinic Endocrinologist John Morris (1997) suggested that TSHR may be a suitable receptor for novel targeted therapies to thyroid cancers, although identified that 'no direct data toward this goal have appeared in the literature'. Although not widely cited, this article defines what has become an increasingly relevant and potentially transformative field.

An early publication by Signore's laboratory in Rome examined radiolabeled rhTSH (either with ${ }^{123}$ I or ${ }^{125}$ I) as a potential imaging tracer for detection of thyroid cancer metastases in a nude-mouse xenograft tumor model, demonstrating focal increase in activity at sites of tumor (Corsetti et al. 2004). A later study similarly examined $\mathrm{Tc}^{99} \mathrm{~m}$-labeled rhTSH injected into CD-1 xenograft mice, and a dog with PTC, and demonstrated focal uptake of radioisotope in TSHR-positive cells (Galli et al. 2014).

The field of theranostics in cancer therapy has rapidly expanded over the past decade, seeking the 'holy grail' of delivery of significant concentrations of drug to target tissues (either a chemotherapeutic agent or imaging tracer) with high specificity and minimal off-target effects, with the goals of increasing therapeutic index (Sercombe et al. 2015). Nanoliposomes offer a well-studied and attractive model for drug delivery and can deliver large payloads per particle. Organ-specific targeting and immune system evasion can be modulated by molecules embedded in the lipid bilayer (Sercombe et al. 2015).

Paolino and coworkers (Paolino et al. 2014) constructed nanoliposomes coated with fragments of TSH. They demonstrated competitive binding to TSHR in vitro, and 3-fold selectivity in localization to thyroid tissue in Wistar rats in vivo. TSHR-targeted nanoliposomes loaded with the chemotherapeutic agent gemcitabine had higher efficacy against the thyroid cancer cell line FTC133 in vitro than non-targeted liposomal gemcitabine and free gemcitabine. Finally, in a xenograft model, TSHRtargeted gemcitabine nanoliposomes resulted in greater reduction of FTC-133 tumor mass over 15 days of therapy than non-targeted gemcitabine liposomes. A similar study the following year confirmed these results using cisplatin (Gao et al. 2015). These studies provide in vivo models to investigate the paradigm of TSHR-targeted theranostics, as liposomes can be readily adapted to deliver either a diagnostic or therapeutic load.

This paradigm was further extended by Dotan and coworkers (Dotan et al. 2016) using bio-affinityfunctionalized carbon-walled nanotubes targeted with either antibodies against TSHR or rhTSH. Such nanotubes are designed to convert electromagnetic energy to thermal energy, and thus, deliver a cytotoxic local thermal load when stimulated by an external nearinfrared light source. In vitro data demonstrated specific cytotoxicity against TSHR-expressing cells from infraredstimulated nanotubes targeted using two commercially available antibodies against TSHR compared to controls, with similar findings using TSH and rhTSH as targeting ligands. Targeting using rhTSH and TSH resulted in greater cytotoxicity than targeting using TSHR antibody. Although this study again provides in vitro evidence for TSHR as a specific theranostic target for thyrocytes, it is unique in suggesting a further method of localizing cytotoxicity using an external infrared light source. This additional external 'targeting' may eliminate off-target cytotoxicity that may be conferred from cytotoxic laden nanoliposomes through non-specific binding, clearance of liposomes in the reticulo-endothelial system or lowdensity binding to non-thyroidal TSHR.

\section{Small-molecule antagonists of TSHR}

Currently, inhibition of TSHR-mediated growth signaling is achieved by pharmacologic suppression of endogenous TSH, with resultant systemic hyperthyroidism. A better system would be a pharmacological antagonist of TSHR, permitting inhibition of thyroid cancer growth while avoiding systemic side effects that limit current widespread use of pharmacologically induced hyperthyroidism. Such small-molecule antagonists of TSHR have significant parallel interest in the treatment of Graves' disease, where stimulatory autoantibodies against TSHR induce marked hyperthyroidism. Davies and Latif (2015), in their recent appraisal of this issue, identify several molecules that have been trialed over the last decade. To date, however, no molecule has been able to achieve sufficient specificity in vivo to substantially inhibit TSHR signaling (inhibition of cAMP production in orbital fibroblasts was $50 \%$ in one study (Neumann et al. 2012)).

\section{Areas for future research}

The described advances suggest a future horizon of targeted therapies for thyroid cancer, where a patient's individual tumor characteristics, such as the surface expression of proteins, can be exploited for selective drug delivery. However, there remain significant obstacles to final clinical translation of these targeted therapies. Additionally, there are several fundamental questions regarding TSHR

Published by Bioscientifica Ltd 
targeting in metastatic DTC that remain unanswered. Firstly, although evidence for TSHR expression on DTC metastases is compelling, it is largely indirect. The density of TSHR expression on metastatic lesions is not well studied, and whether TSHR expression would be sufficient for binding of targeted ligands is not known. Secondly, although TSHR mRNA and TSHR protein have been detected in a variety of tissues, our knowledge of the functional significance of these extrathyroidal TSHR is still in its infancy. Indeed, the density of TSHR expression, and whether non-thyroidal TSHR would bind TSHRtargeted therapies in any significant quantity, would need to be carefully studied, especially in the setting of delivery of cytotoxic therapies. Finally, although there is much interest in redifferentiation therapies for thyroid cancer metastases to upregulate NIS expression, little is known about whether TSHR expression could be upregulated in DTC in a similar manner, and whether such therapies may enhance current or future treatments.

\section{Conclusions}

Although our understanding of the role of the TSHR as a target in thyroid cancer has progressed significantly since the astute clinical observations of the effects of levothyroxine on PTC in the 1930s, our therapeutic abilities to manipulate this system are largely unchanged over several decades. The era of personalized medicine and targeted therapy has cast new light on the TSHR as a potential theranostic target in metastatic DTC. Although promising advances have been made in the last decade, the TSHR invites further study and the possibility of new treatment paradigms for metastatic, radioiodineresistant DTC.

\section{Declaration of interest}

The authors declare that there is no conflict of interest that could be perceived as prejudicing the impartiality of this review.

\section{Funding}

This research was supported by a Hunter New England Local Health District Clinical Research Fellowship, and an AVANT Clinical Research Scholarship (to $C R$ ).

\section{References}

Abe E, Marians RC, Yu W, Wu X-B, Ando T, Li Y, Iqbal J, Eldeiry L, Rajendren G, Blair HC, et al. 2003 TSH is a negative regulator of skeletal remodeling. Cell 115 151-162. (doi:10.1016/S00928674(03)00771-2)
Aghajanova L, Stavreus-Evers A, Lindeberg M, Landgren B-M, Sparre LS \& Hovatta O 2011 Thyroid-stimulating hormone receptor and thyroid hormone receptors are involved in human endometrial physiology. Fertility and Sterility 95 230-237.e232.

Arturi F, Russo D, Giuffrida D, Ippolito A, Perrotti N, Vigneri R \& Filetti S 1997 Early diagnosis by genetic analysis of differentiated thyroid cancer metastases in small lymph nodes. Journal of Clinical Endocrinology and Metabolism 82 1638-1641. (doi:10.1210/ jcem.82.5.4062)

Bahn RS, Dutton CM, Natt N, Joba W, Spitzweg C \& Heufelder AE 1998 Thyrotropin receptor expression in Graves' orbital adipose/ connective tissues: potential autoantigen in Graves' ophthalmopathy. Journal of Clinical Endocrinology and Metabolism $\mathbf{8 3}$ 998-1002. (doi:10.1210/jc.83.3.998)

Balzan S, Nicolini G, Forini F, Boni G, Del Carratore R, Nicolini A, Carpi A \& Iervasi G 2007 Presence of a functional TSH receptor on human erythrocytes. Biomedical Pharmacotherapy 61 463-467. (doi:10.1016/j.biopha.2007.04.009)

Bassett JH \& Williams GR 2016 Role of thyroid hormones in skeletal development and bone maintenance. Endocrine Reviews 37 135-187. (doi:10.1210/er.2015-1106)

Beck-Peccoz P, Persani L, Mannavola D \& Campi I 2009 Pituitary tumours: TSH-secreting adenomas. Best Practice Research in Clinical Endocrinology and Metabolism 23 597-606. (doi:10.1016/j. beem.2009.05.006)

Belfiore A, Garofalo MR, Giuffrida D, Runello F, Filetti S, Fiumara A, Ippolito O \& Vigneri R 1990 Increased aggressiveness of thyroid cancer in patients with Graves' disease. Journal of Clinical Endocrinology and Metabolism 70 830-835. (doi:10.1210/jcem-70-4830)

Bell A, Gagnon A, Grunder L, Parikh SJ, Smith TJ \& Sorisky A 2000 Functional TSH receptor in human abdominal preadipocytes and orbital fibroblasts. American Journal of Physiology 279 C335-C340.

Bodo E, Kromminga A, Biro T, Borbiro I, Gaspar E, Zmijewski MA, Van Beek N, Langbein L, Slominski AT \& Paus R 2009 Human female hair follicles are a direct, nonclassical target for thyroid-stimulating hormone. Journal of Investigative Dermatology 129 1126-1139. (doi:10.1038/jid.2008.361)

Brabant G, Maenhaut C, Köhrle J, Scheumann G, Dralle H, Hoang-Vu C, Hesch RD, Von Zur Mühlen A, Vassart G \& Dumont JE 1991 Human thyrotropin receptor gene: expression in thyroid tumors and correlation to markers of thyroid differentiation and dedifferentiation. Molecular and Cellular Endocrinology 82 R7-R12. (doi:10.1016/0303-7207(91)90018-N)

Bruno R, Ferretti E, Tosi E, Arturi F, Giannasio P, Mattei T, Scipioni A, Presta I, Morisi R, Gulino A, et al. 2005 Modulation of thyroidspecific gene expression in normal and nodular human thyroid tissues from adults: an in vivo effect of thyrotropin. Journal of Clinical Endocrinology and Metabolism 90 5692-5697. (doi:10.1210/ jc.2005-0800)

Carayon P, Thomas-Morvan C, Castanas E \& Tubiana M 1980 Human thyroid cancer: membrane thyrotropin binding and adenylate cyclase activity. Journal of Clinical Endocrinology and Metabolism $\mathbf{5 1}$ 915-920. (doi:10.1210/jcem-51-4-915)

Chabaud O \& Lissitzky S 1977 Thyrotropin-specific binding to human peripheral blood monocytes and polymorphonuclear leukocytes. Molecular and Cellular Endocrinology 7 79-87. (doi:10.1016/03037207(77)90077-6)

Clark OH, Gerend PL, Goretzki P \& Nissenson RA 1983 Characterization of the thyrotropin receptor-adenylate cyclase system in neoplastic human thyroid tissue. Journal of Clinical Endocrinology and Metabolism 57 140-147. (doi:10.1210/jcem-57-1-140)

Cooper DS, Specker B, Ho M, Sperling M, Ladenson PW, Ross DS, Ain KB, Bigos ST, Brierley JD, Haugen BR, et al. 1998 Thyrotropin suppression and disease progression in patients with differentiated thyroid cancer: results from the National Thyroid Cancer Treatment

Published by Bioscientifica Ltd. 
Cooperative Registry. Thyroid 8 737-744. (doi:10.1089/ thy.1998.8.737)

Corsetti F, Chianelli M, Cornelissen B, Van De Wiele C, D'alessandria C, Slegers G, Mather SJ, Di Mario U, Filetti S, Scopinaro F, et al. 2004 Radioiodinated recombinant human TSH: a novel radiopharmaceutical for thyroid cancer metastases detection. Cancer Biotherapy and Radiopharmaceuticals 19 57-63. (doi:10.1089/1084978 04773391685)

Coutelier JP, Kehrl JH, Bellur SS, Kohn LD, Notkins AL \& Prabhakar BS 1990 Binding and functional effects of thyroid stimulating hormone on human immune cells. Journal of Clinical Immunology 10 204-210. (doi:10.1007/bf00918653)

D'agostino M, Sponziello M, Puppin C, Celano M, Maggisano V, Baldan F, Biffoni M, Bulotta S, Durante C, Filetti S, et al. 2014 Different expression of TSH receptor and NIS genes in thyroid cancer: role of epigenetics. Journal of Molecular Endocrinology 52 121-131. (doi:10.1530/jme-13-0160)

Davies T, Marians R \& Latif R 2002 The TSH receptor reveals itself. Journal of Clinical Investigation 110 161-164. (doi:10.1172/ JCI0216234)

Davies TF, Ando T, Lin RY, Tomer Y \& Latif R 2005 Thyrotropin receptor-associated diseases: from adenomata to Graves disease. Journal of Clinical Investigation 115 1972-1983. (doi:10.1172/ JCI26031)

Davies TF \& Latif R 2015 Targeting the thyroid-stimulating hormone receptor with small molecule ligands and antibodies. Expert Opinion on Therapeutic Targets 19 835-847. (doi:10.1517/14728222.2015.1018 181)

Dohán O, Vieja ADL, Paroder V, Riedel C, Artani M, Reed M, Ginter CS \& Carrasco N 2003 The sodium/iodide symporter (NIS): characterization, regulation, and medical significance. Endocrine Reviews 24 48-77. (doi:10.1210/er.2001-0029)

Dotan I, Roche PJ, Paliouras M, Mitmaker EJ \& Trifiro MA 2016 Engineering multi-walled carbon nanotube therapeutic bionanofluids to selectively target papillary thyroid cancer cells. PLOS ONE 11 e0149723. (doi:10.1371/journal.pone.0149723)

Dunhill T 1937 The Lettsomian lectures. The surgery of the thyroid gland. Transactions of the Medical Society of London $60234-282$.

Dutton CM, Joba W, Spitzweg C, Heufelder AE \& Bahn RS 1997 Thyrotropin receptor expression in adrenal, kidney, and thymus. Thyroid 7 879-884.

Edmonds CJ, Hayes S, Kermode JC \& Thompson BD 1977 Measurement of serum TSH and thyroid hormones in the management of treatment of thyroid carcinoma with radioiodine. British Journal of Radiology 50 799-807. (doi:10.1259/0007-1285-50-599-799)

Elisei R, Pinchera A, Romei C, Gryczynska M, Pohl V, Maenhaut C, Fugazzola L \& Pacini F 1994 Expression of thyrotropin receptor (TSH-R), thyroglobulin, thyroperoxidase, and calcitonin messenger ribonucleic acids in thyroid carcinomas: evidence of TSH-R gene transcript in medullary histotype. Journal of Clinical Endocrinology and Metabolism 78 867-871. (doi:10.1210/jc.78.4.867)

Fallahi B, Beiki D, Takavar A, Fard-Esfahani A, Gilani KA, Saghari M \& Eftekhari M 2012 Low versus high radioiodine dose in postoperative ablation of residual thyroid tissue in patients with differentiated thyroid carcinoma: a large randomized clinical trial. Nuclear Medicine Communications 33 275-282. (doi:10.1097/MNM.0b013e32834e306a)

Filetti S, Bidart JM, Arturi F, Caillou B, Russo D \& Schlumberger M 1999 Sodium/iodide symporter: a key transport system in thyroid cancer cell metabolism. European Journal of Endocrinology $141443-457$. (doi:10.1530/eje.0.1410443)

Fiore E, Rago T, Provenzale MA, Scutari M, Ugolini C, Basolo F, Di Coscio G, Berti P, Grasso L, Elisei R, et al. 2009 Lower levels of TSH are associated with a lower risk of papillary thyroid cancer in patients with thyroid nodular disease: thyroid autonomy may play a protective role. Endocrine-Related Cancer 16 1251-1260. (doi:10.1677/ ERC-09-0036)
Franco AT, Malaguarnera R, Refetoff S, Liao X-H, Lundsmith E, Kimura S, Pritchard C, Marais R, Davies TF, Weinstein LS, et al. 2011 Thyrotrophin receptor signaling dependence of Braf-induced thyroid tumor initiation in mice. PNAS 108 1615-1620. (doi:10.1073/pnas.1015557108)

Gagnon A, Langille ML, Chaker S, Antunes TT, Durand J \& Sorisky A 2014 TSH signaling pathways that regulate MCP-1 in human differentiated adipocytes. Metabolism 63 812-821. (doi:10.1016/j.metabol.2014.02.015)

Galli F, Manni I, Piaggio G, Balogh L, Weintraub BD, Szkudlinski MW, Fremont V, Dierckx RA \& Signore A 2014 (99m)Tc-labeled-rhTSH analogue (TR1401) for imaging poorly differentiated metastatic thyroid cancer. Thyroid 24 1297-1308. (doi:10.1089/thy.2013.0429)

Gao X-J, Li A-Q, Zhang X, Liu P, Wang J-R \& Cai X 2015 Thyroidstimulating hormone (TSH)-armed polymer-lipid nanoparticles for the targeted delivery of cisplatin in thyroid cancers: therapeutic efficacy evaluation. Royal Society of Chemistry Advances $\mathbf{5}$ 106413-106420. (doi:10.1039/c5ra12588j)

Gagnon A, Langille ML, Chaker S, Antunes TT, Durand J \& Sorisky A 2014 TSH signaling pathways that regulate MCP-1 in human differentiated adipocytes. Metabolism 63 812-821. (doi:10.1016/j.metabol.2014.02.015)

Gerard AC, Daumerie C, Mestdagh C, Gohy S, De Burbure C, Costagliola S, Miot F, Nollevaux MC, Denef JF, Rahier J, et al. 2003 Correlation between the loss of thyroglobulin iodination and the expression of thyroid-specific proteins involved in iodine metabolism in thyroid carcinomas. Journal of Clinical Endocrinology and Metabolism $\mathbf{8 8}$ 4977-4983. (doi:10.1210/jc.2003-030586)

Giani F, Vella V, Nicolosi ML, Fierabracci A, Lotta S, Malaguarnera R, Belfiore A, Vigneri R \& Frasca F 2015 Thyrospheres from normal or malignant thyroid tissue have different biological, functional, and genetic features. Journal of Clinical Endocrinology and Metabolism $\mathbf{1 0 0}$ E1168-E1178. (doi:10.1210/jc.2014-4163)

Haugen BR, Alexander EK, Bible KC, Doherty GM, Mandel SJ, Nikiforov YE, Pacini F, Randolph GW, Sawka AM, Schlumberger M, et al. 2016 2015 American Thyroid Association Management guidelines for adult patients with thyroid nodules and differentiated thyroid cancer: the American Thyroid Association guidelines task force on thyroid nodules and differentiated thyroid cancer. Thyroid 26 1-133. (doi:10.1089/thy.2015.0020)

Hegedus L, Hansen J \& Karstrup S 1983 High incidence of normal thyroid gland volume in patients with Graves' disease. Clinical Endocrinology 19 603-607. (doi:10.1111/j.1365-2265.1983.tb00037.x)

Hoang-Vu C, Dralle H, Scheumann G, Maenhaut C, Horn R, Von Zur Muhlen A \& Brabant G 1992 Gene expression of differentiation- and dedifferentiation markers in normal and malignant human thyroid tissues. Experimental and Clinical Endocrinology 100 51-56. (doi:10.10 55/s-0029-1211176)

Hurley JR 2011 Historical note: TSH suppression for thyroid cancer. Thyroid 21 1175-1176. (doi:10.1089/thy.2011.2111.com)

Ichikawa Y, Saito E, Abe Y, Homma M \& Muraki T 1976 Presence of TSH receptor in thyroid neoplasms. Journal of Clinical Endocrinology and Metabolism 42 395-398. (doi:10.1210/jcem-42-2-395)

Jarzab B, Handkiewicz-Junak D, Roskosz J, Puch Z, Wygoda Z, Kukulska A, Jurecka-Lubieniecka B, Hasse-Lazar K, Turska M \& Zajusz A 2003 Recombinant human TSH-aided radioiodine treatment of advanced differentiated thyroid carcinoma: a single-centre study of 54 patients. European Journal of Nuclear Medicine and Molecular Imaging 30 1077-1086. (doi:10.1007/s00259-003-1190-5)

Jonklaas J, Sarlis NJ, Litofsky D, Ain KB, Bigos ST, Brierley JD, Cooper DS, Haugen BR, Ladenson PW, Magner J, et al. 2006 Outcomes of patients with differentiated thyroid carcinoma following initial therapy. Thyroid 16 1229-1242. (doi:10.1089/thy.2006.16.1229)

Kim YH, Choi YW, Han JH, Lee J, Soh EY, Park SH, Kim J-H \& Park TJ 2014 TSH Signaling overcomes B-RafV600E-induced senescence in papillary thyroid carcinogenesis through regulation of DUSP6. Neoplasia 16 1107-1120. (doi:10.1016/j.neo.2014.10.005)

Kimura T, Van Keymeulen A, Golstein J, Fusco A, Dumont JE \& Roger PP 2001 Regulation of thyroid cell proliferation by TSH and other

Published by Bioscientifica Ltc. 
factors: a critical evaluation of in vitro models. Endocrine Reviews 22 631-656. (doi:10.1210/edrv.22.5.0444)

Lazar V, Bidart JM, Caillou B, Mahe C, Lacroix L, Filetti S \& Schlumberger M 1999 Expression of the Na+/I- symporter gene in human thyroid tumors: a comparison study with other thyroidspecific genes. Journal of Clinical Endocrinology and Metabolism 84 3228-3234. (doi:10.1210/jc.84.9.3228)

Leboulleux S, Schroeder PR, Busaidy NL, Auperin A, Corone C, Jacene HA, Ewertz ME, Bournaud C, Wahl RL, Sherman SI, et al. 2009 Assessment of the incremental value of recombinant thyrotropin stimulation before 2-[18F]-Fluoro-2-deoxy-D-glucose positron emission tomography/computed tomography imaging to localize residual differentiated thyroid cancer. Journal of Clinical Endocrinology and Metabolism 94 1310-1316. (doi:10.1210/jc.2008-1747)

Lin JD, Fu SS, Chen JY, Lee CH, Chau WK, Cheng CW, Wang YH, Lin YF, Fang WF \& Tang KT 2016 Clinical manifestations and gene expression in patients with conventional papillary thyroid carcinoma carrying the BRAF(V600E) mutation and BRAF pseudogene. Thyroid 26 691-704. (doi:10.1089/thy.2015.0044)

Lippi F, Capezzone M, Angelini F, Taddei D, Molinaro E, Pinchera A \& Pacini F 2001 Radioiodine treatment of metastatic differentiated thyroid cancer in patients on L-thyroxine, using recombinant human TSH. European Journal of Endocrinology 144 5-11. (doi:10.1530/eje.0.1440005)

Liu TR, Su X, Qiu WS, Chen WC, Men QQ, Zou L, Li ZQ, Fu XY \& Yang AK 2016 Thyroid-stimulating hormone receptor affects metastasis and prognosis in papillary thyroid carcinoma. European Review for Medical and Pharmacological Science 20 3582-3591.

Lu C, Zhao L, Ying H, Willingham MC \& Cheng SY 2010 Growth activation alone is not sufficient to cause metastatic thyroid cancer in a mouse model of follicular thyroid carcinoma. Endocrinology 151 1929-1939. (doi:10.1210/en.2009-1017)

Luster M, Lassmann M, Haenscheid H, Michalowski U, Incerti C \& Reiners C 2000 Use of recombinant human thyrotropin before radioiodine therapy in patients with advanced differentiated thyroid carcinoma. Journal of Clinical Endocrinology and Metabolism $\mathbf{8 5}$ 3640-3645. (doi:10.1210/jcem.85.10.6903)

Luster M, Lippi F, Jarzab B, Perros P, Lassmann M, Reiners C \& Pacini F 2005 rhTSH-aided radioiodine ablation and treatment of differentiated thyroid carcinoma: a comprehensive review. EndocrineRelated Cancer 12 49-64. (doi:10.1677/erc.1.00830)

Ma R, Morshed S, Latif R, Zaidi M \& Davies TF 2011 The influence of thyroid-stimulating hormone and thyroid-stimulating hormone receptor antibodies on osteoclastogenesis. Thyroid 21 897-906. (doi:10.1089/thy.2010.0457)

Maenhaut C, Brabant G, Vassart G \& Dumont JE 1992 In vitro and in vivo regulation of thyrotropin receptor mRNA levels in dog and human thyroid cells. Journal of Biological Chemistry 267 3000-3007.

Malaguarnera R, Frasca F, Garozzo A, Giani F, Pandini G, Vella V, Vigneri $\mathrm{R} \&$ Belfiore A 2011 Insulin receptor isoforms and insulin-like growth factor receptor in human follicular cell precursors from papillary thyroid cancer and normal thyroid. Journal of Clinical Endocrinology and Metabolism 96 766-774. (doi:10.1210/jc.2010-1255)

Matsumoto H, Sakamoto A, Fujiwara M, Yano Y, Shishido-Hara Y, Fujioka Y \& Kamma H 2008 Decreased expression of the thyroidstimulating hormone receptor in poorly-differentiated carcinoma of the thyroid. Oncology Reports 19 1405-1411. (doi:10.3892/ ijmm.2012.1173)

Mazzaferri EL \& Jhiang SM 1994 Long-term impact of initial surgical and medical therapy on papillary and follicular thyroid cancer. American Journal of Medicine 97 418-428. (doi:10.1016/00029343(94)90321-2)

McGriff NJ, Csako G, Gourgiotis L, Lori CG, Pucino F \& Sarlis NJ 2002 Effects of thyroid hormone suppression therapy on adverse clinical outcomes in thyroid cancer. Annals of Medicine 34 554-564. (doi:10.1 080/078538902321117760)
Meireles AM, Preto A, Rocha AS, Rebocho AP, Maximo V, Pereira-Castro I, Moreira S, Feijao T, Botelho T, Marques R, et al. 2007 Molecular and genotypic characterization of human thyroid follicular cell carcinoma-derived cell lines. Thyroid 17 707-715. (doi:10.1089/ thy.2007.0097)

Morris JC 1997 Structure and function of the TSH receptor: its suitability as a target for radiotherapy. Thyroid 7 253-258. (doi:10.1089/ thy.1997.7.253)

Morshed SA, Latif R \& Davies TF 2009 Characterization of thyrotropin receptor antibody-induced signaling cascades. Endocrinology $\mathbf{1 5 0}$ 519-529. (doi:10.1210/en.2008-0878)

Murakami M, Hosoi Y, Negishi T, Kamiya Y, Miyashita K, Yamada M, Iriuchijima T, Yokoo H, Yoshida I, Tsushima Y, et al. 1996 Thymic hyperplasia in patients with Graves' disease. Identification of thyrotropin receptors in human thymus. Journal of Clinical Investigation 98 2228-2234. (doi:10.1172/jci119032)

Murakami M, Kamiya Y, Morimura T, Araki O, Imamura M, Ogiwara T, Mizuma H \& Mori M 2001 Thyrotropin receptors in brown adipose tissue: thyrotropin stimulates type II iodothyronine deiodinase and uncoupling protein-1 in brown adipocytes. Endocrinology 142 1195-1201. (doi:10.1210/en.142.3.1195)

Neumann S, Pope A, Geras-Raaka E, Raaka BM, Bahn RS \& Gershengorn MC 2012 A drug-like antagonist inhibits thyrotropin receptormediated stimulation of cAMP production in Graves' orbital fibroblasts. Thyroid 22 839-843. (doi:10.1089/thy.2011.0520)

Nieto HR \& Boelaert K 2016 Thyroid stimulating hormone in thyroid cancer: does it matter? Endocrine-Related Cancer 23 T109-T121. (doi:10.1530/ERC-16-0328)

Ohta K, Endo T \& Onaya T 1991 The mRNA levels of thyrotropin receptor, thyroglobulin and thyroid peroxidase in neoplastic human thyroid tissues. Biochemical and Biophysical Research Communications 174 1148-1153. (doi:10.1016/0006-291X(91)91540-S)

Paolino D, Cosco D, Gaspari M, Celano M, Wolfram J, Voce P, Puxeddu E, Filetti S, Celia C, Ferrari M, et al. 2014 Targeting the thyroid gland with thyroid-stimulating hormone (TSH)nanoliposomes. Biomaterials 35 7101-7109. (doi:10.1016/j. biomaterials.2014.04.088)

Park HJ, Kim JY, Park KY, Gong G, Hong SJ \& Ahn IM 2000 Expressions of human sodium iodide symporter mRNA in primary and metastatic papillary thyroid carcinomas. Thyroid 10 211-217. (doi:10.1089/thy.2000.10.211)

Parmentier M, Libert F, Maenhaut C, Lefort A, Gerard C, Perret J, Van Sande J, Dumont JE \& Vassart G 1989 Molecular cloning of the thyrotropin receptor. Science 246 1620-1622. (doi:10.1126/ science.2556796)

Pellegriti G, Mannarino C, Russo M, Terranova R, Marturano I, Vigneri R \& Belfiore A 2013 Increased mortality in patients with differentiated thyroid cancer associated with Graves' disease. Journal of Clinical Endocrinology and Metabolism 98 1014-1021. (doi:10.1210/jc.20122843)

Pilli T, Prasad KV, Jayarama S, Pacini F \& Prabhakar BS 2009 Potential utility and limitations of thyroid cancer cell lines as models for studying thyroid cancer. Thyroid 19 1333-1342. (doi:10.1089/ thy.2009.0195)

Prummel MF, Brokken LJ, Meduri G, Misrahi M, Bakker O \& Wiersinga WM 2000 Expression of the thyroid-stimulating hormone receptor in the folliculo-stellate cells of the human anterior pituitary. Journal of Clinical Endocrinology and Metabolism 85 4347-4353. (doi:10.1210/jc.85.11.4347)

Pujol P, Daures JP, Nsakala N, Baldet L, Bringer J \& Jaffiol C 1996 Degree of thyrotropin suppression as a prognostic determinant in differentiated thyroid cancer. Journal of Clinical Endocrinology and Metabolism 81 4318-4323. (doi:10.1210/jc.81.12.4318)

Rapoport B \& Mclachlan SM 2016 TSH receptor cleavage into subunits and shedding of the A-Subunit; a molecular and clinical perspective. Endocrine Reviews 37 114-134. (doi:10.1210/er.2015-1098) 
Rees Smith B, Mclachlan SM \& Furmaniak J 1988 Autoantibodies to the thyrotropin receptor. Endocrine Reviews 9 106-121. (doi:10.1210/ edrv-9-1-106)

Roger P, Taton M, Van Sande J \& Dumont J 1988 Mitogenic effects of thyrotropin and adenosine $3^{\prime}, 5^{\prime}$-monophosphate in differentiated normal human thyroid cells in vitro. Journal of Clinical Endocrinology and Metabolism 66 1158-1165. (doi:10.1210/jcem-66-6-1158)

Saito T, Endo T, Kawaguchi A, Ikeda M, Nakazato M, Kogai T \& Onaya T 1997 Increased expression of the $\mathrm{Na}+$ /I- symporter in cultured human thyroid cells exposed to thyrotropin and in Graves' thyroid tissue. Journal of Clinical Endocrinology and Metabolism 82 3331-3336. (doi:10.1210/endo.138.2.4918)

Schuppert F, Deiters S, Rambusch E, Sierralta W, Dralle H \& Von Zur Muhlen A 1996 TSH-receptor expression and human thyroid disease: relation to clinical, endocrine, and molecular thyroid parameters. Thyroid 6 575-587. (doi:10.1089/thy.1996.6.575)

Sciuto R, Romano L, Rea S, Marandino F, Sperduti I \& Maini CL 2009 Natural history and clinical outcome of differentiated thyroid carcinoma: a retrospective analysis of 1503 patients treated at a single institution. Annals of Oncology 20 1728-1735. (doi:10.1093/ annonc/mdp050)

Sellitti DF, Akamizu T, Doi SQ, Kim GH, Kariyil JT, Kopchik JJ \& Koshiyama H 2000 Renal expression of two 'thyroid-specific' genes: thyrotropin receptor and thyroglobulin. Experimental Nephrology $\mathbf{8}$ 235-243. (doi:10.1159/000020674)

Sercombe L, Veerati T, Moheimani F, Wu SY, Sood AK \& Hua S 2015 Advances and challenges of liposome assisted drug delivery. Frontiers in Pharmacology 6 286. (doi:10.3389/fphar.2015.00286)

Sheils OM \& Sweeney EC 1999 TSH receptor status of thyroid neoplasms - TaqMan RT-PCR analysis of archival material. Journal of Pathology 188 87-92. (doi:10.1002/(SICI)1096-9896(199905)188:1<87::AIDPATH322>3.0.CO;2-5)

Shi Y, Zou M \& Farid NR 1993 Expression of thyrotrophin receptor gene in thyroid carcinoma is associated with a good prognosis. Clinical Endocrinology 39 269-274. (doi:10.1111/j.1365-2265.1993.tb02365.x)

Smith TJ 2015 TSH-receptor-expressing fibrocytes and thyroid-associated ophthalmopathy. Nature Reviews Endocrinology 11 171-181. (doi:10.1038/nrendo.2014.226)

So YK, Son YI, Baek CH, Jeong HS, Chung MK \& Ko YH 2012 Expression of sodium-iodide symporter and TSH receptor in subclinical metastatic lymph nodes of papillary thyroid microcarcinoma. Annals of Surgical Oncology 19 990-995. (doi:10.1245/s10434-011-2047-y)

Tanaka K, Inoue H, Miki H, Masuda E, Kitaichi M, Komaki K, Uyama T \& Monden Y 1997 Relationship between prognostic score and thyrotropin receptor (TSH-R) in papillary thyroid carcinoma: immunohistochemical detection of TSH-R. British Journal of Cancer 76 594-599. (doi:10.1038/bjc.1997.431)

Tanaka K, Otsuki T, Sonoo H, Yamamoto Y, Udagawa K, Kunisue H, Arime I, Yamamoto S, Kurebayashi J \& Shimozuma K 2000 Semiquantitative comparison of the differentiation markers and sodium iodide symporter messenger ribonucleic acids in papillary thyroid carcinomas using RT-PCR. European Journal of Endocrinology 142 340-346. (doi:10.1530/eje.0.1420340)

Theodoropoulou M, Arzberger T, Gruebler Y, Korali Z, Mortini P, Joba W, Heufelder A, Stalla G \& Schaaf L 2000 Thyrotrophin receptor protein expression in normal and adenomatous human pituitary. Journal of Endocrinology 167 7-13. (doi:10.1677/joe.0.1670007)

Tian L, Ni J, Guo T, Liu J, Dang Y, Guo Q \& Zhang L 2014 TSH stimulates the proliferation of vascular smooth muscle cells. Endocrine 46 651-658. (doi:10.1007/s12020-013-0135-4)

Valyasevi RW, Erickson DZ, Harteneck DA, Dutton CM, Heufelder AE, Jyonouchi SC \& Bahn RS 1999 Differentiation of human orbital preadipocyte fibroblasts induces expression of functional thyrotropin receptor. Journal of Clinical Endocrinology and Metabolism 84 2557-2562. (doi:10.1210/jc.84.7.2557)

Van Staveren WCG, Solís DW, Delys L, Duprez L, Andry G, Franc B, Thomas G, Libert F, Dumont JE, Detours V, et al. 2007 Human thyroid tumor cell lines derived from different tumor types present a common dedifferentiated phenotype. Cancer Research 67 8113-8120. (doi:10.1158/0008-5472.CAN-06-4026)

Vassart G \& Dumont JE 1992 The thyrotropin receptor and the regulation of thyrocyte function and growth. Endocrine Reviews 13 596-611. (doi:10.1210/er.13.3.596)

Wang ZF, Liu QJ, Liao SQ, Yang R, Ge T, He X, Tian CP \& Liu W 2011 Expression and correlation of sodium/iodide symporter and thyroid stimulating hormone receptor in human thyroid carcinoma. Tumori 97 540-546. (doi:10.1700/950.10410)

Williams GR 2011 Extrathyroidal expression of TSH receptor. Annals of Endocrinology 72 68-73. (doi:10.1016/j.ando.2011.03.006)

Williams D \& Wynford-Thomas D 1997 Human thyroid epithelial cells In Methods in Molecular Biology. Totowa, NJ, USA: Humana Press, Inc.

Zhang W, Tian LM, Han Y, Ma HY, Wang LC, Guo J, Gao L \& Zhao JJ 2009 Presence of thyrotropin receptor in hepatocytes: not a case of illegitimate transcription. Journal of Cellular and Molecular Medicine 13 4636-4642. (doi:10.1111/j.1582-4934.2008.00670.x)

Zielke A, Tezelman S, Jossart GH, Wong M, Siperstein AE, Duh QY \& Clark OH 1998 Establishment of a highly differentiated thyroid cancer cell line of Hurthle cell origin. Thyroid 8 475-483. (doi:10.1089/thy.1998.8.475)

Received in final form 14 March 2017

Accepted 28 March 2017

Accepted Preprint published online 28 March 2017
(C) 2017 Society for Endocrinology Printed in Great Britain
Published by Bioscientifica Ltd. 